\title{
Genetic Divergence for Quantitative and Quality Traits in Rice (Oryza sativa L.)
}

\author{
Thippannagari Radha, P. Satheesh Kumar* and K. Saravanan
}

Department of Genetics and Plant Breeding, Faculty of Agriculture, Annamalai University, Annamalainagar 608 002, India

*Corresponding author

\begin{tabular}{|l|}
\hline Ke y w or d s \\
$\begin{array}{l}\text { Cluster analysis, } \\
\text { Quantitative, } \\
\text { Quality, Rice }\end{array}$ \\
\hline Article Info \\
\hline $\begin{array}{l}\text { Accepted: } \\
\text { 07 April } 2018 \\
\text { Available Online: } \\
\text { 10 May } 2018\end{array}$ \\
\hline
\end{tabular}

\section{Introduction}

Rice is a cereal crop belonging to genus Oryza of family Poaceae. About half of the world's population depends on rice for their survival. Rice is being cultivated in around 113 countries of the world. The present world rice area, production and productivity is 158.93 mha, $465.03 \mathrm{mt}$ and $4.36 \mathrm{t} / \mathrm{ha}$, respectively. In India, it is being grown in 45.10 mha area with production of $103.60 \mathrm{mt}$ and productivity of $3.51 \mathrm{t} / \mathrm{ha}$ and contributes $25 \%$ to agricultural
An investigation was carried out with 42 genotypes of rice to study the nature and magnitude of genetic divergence using Mahalanobis $\mathrm{D}^{2}$ statistics. Based on 12 morphological quantitative and quality characters namely, days to 50 per cent flowering, plant height, number of productive tillers per plant, panicle length, hundred grain weight, grain length, grain breadth, grain L/B ratio, kernel length, kernel breadth, kernel L/B ratio and grain yield per plant, these genotypes were grouped into six clusters. Cluster III with sixteen genotypes was the largest cluster followed by cluster VI with thirteen genotypes. Cluster I (7 genotypes), clusters II, IV and V comprised two genotypes each were also observed. Geographical origin was not found to be a good parameter of genetic divergence. The intra cluster distance was maximum $(\mathrm{D}=174.228)$ in cluster VI. The maximum inter cluster distance $(\mathrm{D}=230.709)$ was recorded between clusters II and VI. Cluster VI recorded highest mean value for hundred grain weight, kernel length, kernel L/B ratio and grain yield per plant. Grain yield per plant (46.69 per cent) followed by kernel length (18.28 per cent) and hundred grain weight (14.96 per cent) contributed maximum to total divergence. Hybridization among genotypes from II and VI which had maximum inter cluster distances and desirable values for quantitative and quality traits is likely to produce heterotic combinations and wide variability in segregating generations. 
The estimation of genetic diversity between different genotypes in the crop of interest is the first and foremost process in any plant breeding programme. However assessment of genetic diversity of rice has not given much thrust. We need to identify the genetically diverse accession with desired genes for better utilization in crop breeding programme. Hence the present study was undertaken to evaluate 42 rice genotypes for genetic divergence.

\section{Materials and Methods}

The experimental material comprised of 42 genotypes (Table 1) were evaluated during samba season (September-January) 2014 and 2015 at the Plant Breeding Farm $\left(11^{\circ} 24^{\prime} \mathrm{N}\right.$ latitude and $79^{\circ} 44^{\prime} \mathrm{E}$ longitude $\pm 5.79 \mathrm{~m}$ MSL), Annamalai University, Annamalainagar, Tamilnadu, South India. Seeds of the 42 genotypes were sown in raised nursery bed. The seedlings were transplanted to the mainfield at the rate of one seedling per hill, after 25 days, with a spacing of $20 \mathrm{~cm} \times$ $15 \mathrm{~cm}$. The experiment was arranged in a randomized complete block design with three replications, in four - row plots of $3 \mathrm{~m}$ length.

The recommended agronomical practices and plant protection measures were followed to ensure a normal crop. Observations were recorded on five randomly selected plants in each replication from the two centre rows. Twelve traits viz., days to 50 per cent flowering, plant height $(\mathrm{cm})$, number of productive tillers per plant, panicle length (cm), hundred grain weight $(\mathrm{g})$, grain length $(\mathrm{mm})$, grain breadth $(\mathrm{mm})$, grain $\mathrm{L} / \mathrm{B}$ ratio, kernel length $(\mathrm{mm})$, kernel breadth $(\mathrm{mm})$, kernel L/B ratio and grain yield per plant (g) were recorded. Mahalanobis (1936) $\mathrm{D}^{2}$ analysis Sarawagi and Rita Binse (2007) was used to estimate genetic divergence among the 42 genotypes. Grouping of genotypes into clusters was carried out following Tocher's Methods Rao (1952). Mean value of the variables, calculated based on measurements on plants from blocks and each genotype, were used in the cluster analysis.

\section{Results and Discussion}

The analysis of variance showed significant difference among the forty two genotypes for all the twelve characters indicating the existence of high genetic variability among the genotypes for all the traits (Table 2). The forty two genotypes were grouped in to six different clusters based on the relative magnitude of $\mathrm{D}^{2}$ values.

Cluster III, the largest cluster, comprised sixteen genotypes, followed by cluster VI with thirteen genotypes (Table 4). The cluster I with seven genotypes, the clusters II, IV and V comprised two genotypes each. The clustering pattern revealed that the genotypes from different sources clustered together indication that there was no association between ecogeographical distribution of genotypes and genetic divergence. The possible reason for grouping of genotypes of different states in one cluster could be the free exchange of germplasm among the breeders of different regions, or unidirectional selection practiced by breeder in tailoring the promising cultivars for different regions Verma and Mehta (1976). Similar findings were reported by Chaturvedi and Maurya (2005), Sabesan and Saravanan (2008) and Bhati et al., (2015). This indicated that, in general selection has been towards the same goal in the different centers of origin of these genotypes and yet, there is sufficient genetic variability, which distinctly differentiates them into six clusters. On the other hand, our study has also revealed that genotypes from the same centre of origin were distributed in different clusters, which may be due to differential adaptation to varied agroecosystems Kandamoorthy and Govindarasu (2005), Sabesan et al., (2009) and Kumari Priyanka et al., (2015). 
Table.1 List of genotypes selected for $\mathrm{D}^{2}$ analysis

\begin{tabular}{|c|l|l|}
$\begin{array}{l}\text { Genotype } \\
\text { code }\end{array}$ & Genotype names & Origin \\
\hline G1 & ADT-36 & Tamil Nadu Rice Research Institute (TRRI), Aduturai, Tamil Nadu, India. \\
\hline G2 & ADT-37 & Tamil Nadu Rice Research Institute (TRRI), Aduturai, Tamil Nadu, India. \\
\hline G3 & ADT-38 & Tamil Nadu Rice Research Institute (TRRI), Aduturai, Tamil Nadu, India. \\
\hline G4 & ADT-39 & Tamil Nadu Rice Research Institute (TRRI), Aduturai, Tamil Nadu, India. \\
\hline G5 & ADT-40 & Tamil Nadu Rice Research Institute (TRRI), Aduturai, Tamil Nadu, India. \\
\hline G6 & ADT-41 & Tamil Nadu Rice Research Institute (TRRI), Aduturai, Tamil Nadu, India. \\
\hline G7 & ADT-42 & Tamil Nadu Rice Research Institute (TRRI), Aduturai, Tamil Nadu, India. \\
\hline G8 & ADT-43 & Tamil Nadu Rice Research Institute (TRRI), Aduturai, Tamil Nadu, India. \\
\hline G9 & ADT-44 & Tamil Nadu Rice Research Institute (TRRI), Aduturai, Tamil Nadu, India. \\
\hline G10 & ADT-45 & Tamil Nadu Rice Research Institute (TRRI), Aduturai, Tamil Nadu, India. \\
\hline G11 & ADT-46 & Tamil Nadu Rice Research Institute (TRRI), Aduturai, Tamil Nadu, India. \\
\hline G12 & ADT-47 & Tamil Nadu Rice Research Institute (TRRI), Aduturai, Tamil Nadu, India. \\
\hline G13 & ADT-48 & Tamil Nadu Rice Research Institute (TRRI), Aduturai, Tamil Nadu, India. \\
\hline G14 & ADT-49 & Tamil Nadu Rice Research Institute (TRRI), Aduturai, Tamil Nadu, India. \\
\hline G15 & CR-1009 & Central Rice Research Institute (CRRI), Cuttack, Orissa, India. \\
\hline G16 & BPT-5204 & Agriculture college, Bapatla, Andhra Pradesh, India. \\
\hline G17 & IR-64 & International Rice Research Institute (IRRI), Philippines. \\
\hline G18 & WHITE PONNI & Paddy breeding station, Coimbatore, Tamil Nadu, India. \\
\hline G19 & TRY-1 & Agricultural College and Research Institute, Trichy, Tamil Nadu, India. \\
\hline G20 & TRY-2 & Agricultural College and Research Institute, Trichy, Tamil Nadu, India. \\
\hline G21 & TRY-3 & Agricultural College and Research Institute, Trichy, Tamil Nadu, India. \\
\hline
\end{tabular}

Contd...

\begin{tabular}{|c|l|l|}
$\begin{array}{l}\text { Genotype } \\
\text { code }\end{array}$ & Genotype names & Origin \\
\hline G22 & CSR-30 & Central Saline Soil Research Institute (CSSRI), Karnal, Haryana, India. \\
\hline G23 & ANANDA & Gujarat, India. \\
\hline G24 & CO-49 & Paddy Breeding Station, Coimbatore, Tamil Nadu, India. \\
\hline G25 & MTU-1001 & Rice Research Station, Marteru, Andhra Pradesh, India. \\
\hline G26 & MARANTHONDI & Traditional Variety, Kerala, India. \\
\hline G27 & MDU-5 & Agriculture College and Research Institute, Madurai, India. \\
\hline G28 & SWATHI & Directorate of Rice Research (DRR), Hyderabad, Andhra Pradesh, India. \\
\hline G29 & MTU-1010 & Rice Research Station, Marteru, Andhra Pradesh, India. \\
\hline G30 & ASD-16 & Rice Research Station, Ambasamuthiram, Tamil Nadu, India. \\
\hline G31 & ASD-17 & Rice Research Station, Ambasamuthiram, Tamil Nadu, India. \\
\hline G32 & ASD-19 & Rice Research Station, Ambasamuthiram, Tamil Nadu, India. \\
\hline G33 & MAHAMAYA & Indira Gandhi Krishi Vishwavidyalaya, Raipur (Chhattisgarh), India. \\
\hline G34 & POORNIMA & Indira Gandhi Krishi Vishwavidyalaya, Raipur (Chhattisgarh), India. \\
\hline G35 & KARMA MAHSURI & Indira Gandhi Krishi Vishwavidyalaya, Raipur (Chhattisgarh), India. \\
\hline G36 & JALAKARA PONNI & Traditional variety, Tamil Nadu, India. \\
\hline G37 & SHYAMALA & Indira Gandhi Krishi Vishwavidyalaya, Raipur (Chhattisgarh), India. \\
\hline G38 & ANNAPURNA & Regional Agricultural Research Station, Pattambi, Kerala, India. \\
\hline G39 & ASD-18 & Rice Research Station, Ambasamuthiram, Tamil Nadu, India. \\
\hline G40 & BPT-5202 & Agriculture college, Bapatla, Andhra Pradesh, India. \\
\hline G41 & GAYATHRI & Central Rice Research Institute (CRRI), Cuttack, Orissa, India. \\
\hline G42 & SWARNA & Rice Research Station, Marteru, Andhra Pradesh, India. \\
\hline
\end{tabular}


Table.2 Analysis of variance for 12 morphological characters in 42 rice genotypes

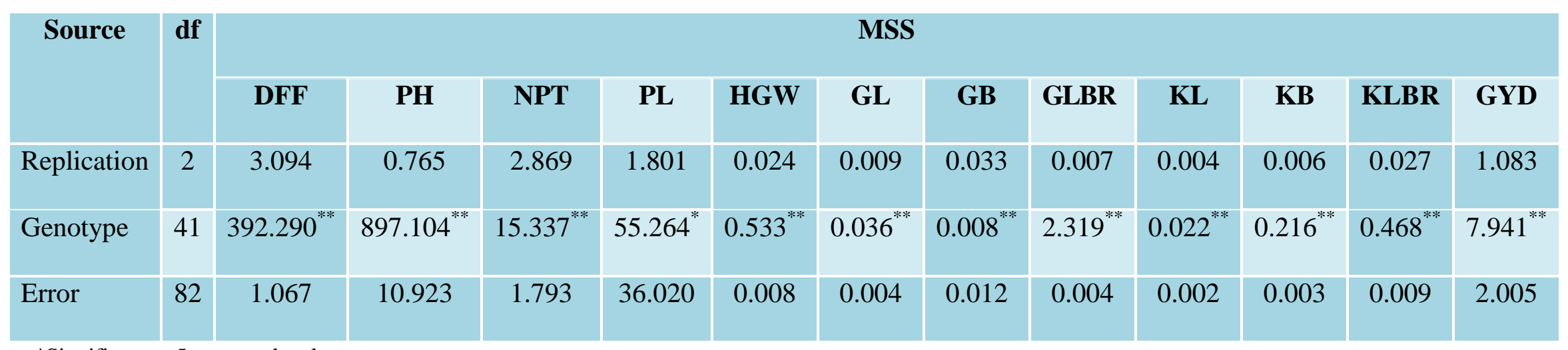

*Significant at 5 per cent level

**Significant at 1 Per cent level

Table.3 Cluster means of 42 rice genotypes for various characters

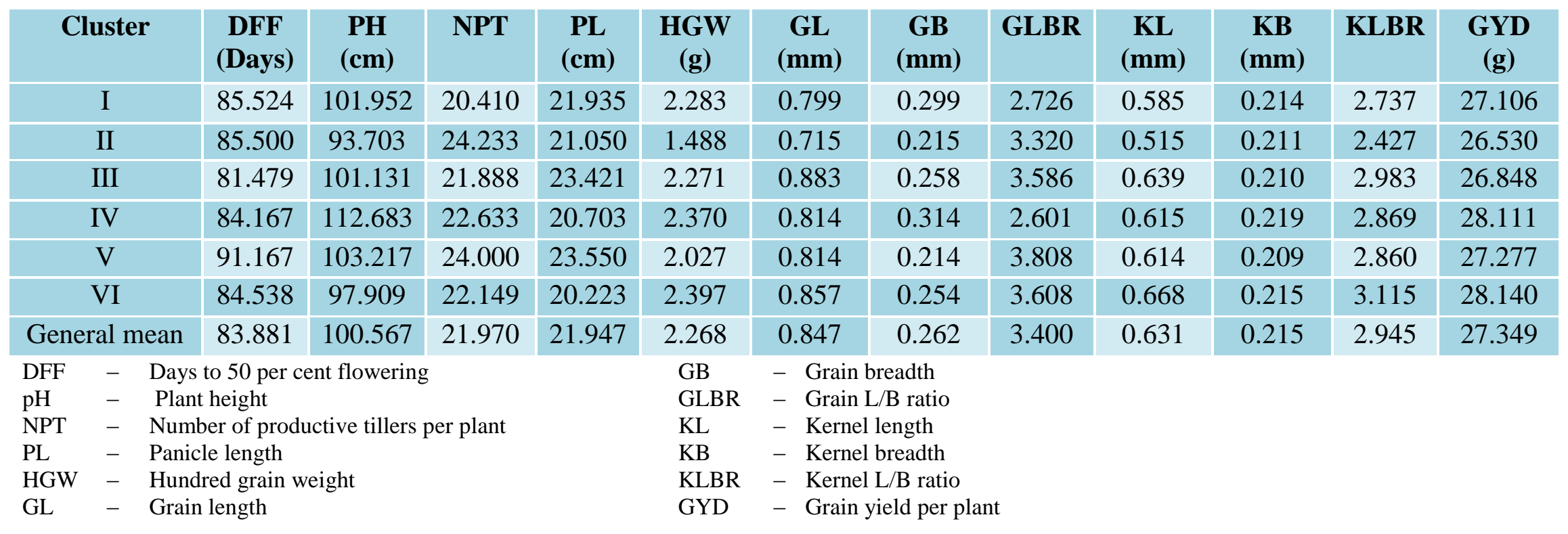


Table.4 Composition of $\mathrm{D}^{2}$ clusters for 42 rice genotypes

\begin{tabular}{|c|c|c|}
\hline Cluster & $\begin{array}{l}\text { Number of } \\
\text { genotypes }\end{array}$ & Name of genotypes \\
\hline I & 7 & ADT36, ADT37, ADT38, ADT39, ADT40, MTU1001, MDU5 \\
\hline II & 2 & ADT47, ADT49 \\
\hline III & 16 & $\begin{array}{l}\text { ADT41, ADT42, ADT43, ADT44, ADT45, ADT46, ADT48, CR1009, } \\
\text { BPT5204, IR64, WHITE PONNI, TRY1, TRY2, TRY3, ASD17, } \\
\text { BPT5202 }\end{array}$ \\
\hline IV & 2 & POORNIMA, SWARNA \\
\hline V & 2 & CO49, MAHAMAYA \\
\hline VI & 13 & $\begin{array}{l}\text { CSR30, ANANDA, MARANTHONDI, SWATHI, MTU1010, ASD16, } \\
\text { ASD19, KARMA, MAHSURI, JALAKARA PONNI, SHYAMALA, } \\
\text { ANNAPURNA, ASD 18, GAYATHRI }\end{array}$ \\
\hline
\end{tabular}

Table.5 Average inter $\left(\mathrm{D}^{2}\right)$ and intra (D) cluster values for 42 rice genotypes

\begin{tabular}{|c|c|c|c|c|c|c|}
\hline Cluster & I & II & III & IV & V & VI \\
\hline I & 17614.209 & 25457.107 & 22801.158 & 8211.706 & 12961.501 & 30810.082 \\
& $(132.719)$ & $(159.553)$ & $(151.001)$ & $(90.618)$ & $(113.849)$ & $(175.528)$ \\
\hline II & & 62.919 & 38001.336 & 24008.752 & 17083.168 & 53226.840 \\
& & $(7.932)$ & $(194.939)$ & $(154.948)$ & $(130.703)$ & $(230.709)$ \\
\hline III & & & 21626.939 & 13728.705 & 12038.848 & 25159.533 \\
& & & $(147.061)$ & $(117.170)$ & $(109.722)$ & $(158.618)$ \\
\hline IV & & & & 129.204 & 5629.074 & 20246.965 \\
& & & & $(11.367)$ & $(75.027)$ & $(142.292)$ \\
\hline V & & & & & 311.559 & 19106.977 \\
& & & & & $(17.651)$ & $(138.228)$ \\
\hline VI & & & & & & 30355.225 \\
& & & & & & \\
\hline
\end{tabular}

Table.6 Contribution of different characters to genetic divergence

\begin{tabular}{|c|l|c|}
\hline S. No. & Characters & Contribution of each characters (\%) \\
\hline 1 & Days to 50 per cent flowering (days) & 1.54 \\
\hline 2 & Plant height $(\mathrm{cm})$ & 0.17 \\
\hline 3 & Number of productive tillers per plant & 1.20 \\
\hline 4 & Panicle length $(\mathrm{cm})$ & 2.35 \\
\hline 5 & Hundred grain weight $(\mathrm{g})$ & 14.96 \\
\hline 6 & Grain length $(\mathrm{mm})$ & 0.32 \\
\hline 7 & Grain breadth $(\mathrm{mm})$ & 0.41 \\
\hline 8 & Grain L/B ratio & 8.81 \\
\hline 9 & Kernel length $(\mathrm{mm})$ & 18.28 \\
\hline 10 & Kernel breadth $(\mathrm{mm})$ & 4.37 \\
\hline 11 & Kernel L/B ratio & 0.90 \\
\hline 12 & Grain yield per plant $(\mathrm{g})$ & 46.69 \\
\hline
\end{tabular}


The relative divergence of each from other cluster i.e., inter-cluster distance indicated greater divergence between cluster II and cluster VI $\left(D^{2}=230.709\right)$. It was characterized by genotypes with heavier grain yield per plant and low hundred grain weight (Table 5). It was followed by cluster II and cluster III $\left(D^{2}=\right.$ 194.939) with cluster II having highest number of productive tillers per plant and cluster III with earliness in days to 50 per cent flowering. Parental lines selected from these clusters may be used in hybridization programme, since hybridization between divergent parents is likely to produce wide variability and transgressive segregations with high heterotic effects (Rama, 1992). Such recommendations were also made by Sabesan et al., (2009) and Satheeshkumar and Saravanan (2012). The smallest inter-cluster distance was observed between clusters IV and V $\left(\mathrm{D}^{2}=75.027\right)$ followed by cluster I and IV $\left(\mathrm{D}^{2}=90.618\right)$. The lines belonging to these clusters were relatively closer to each other, in comparison to lines grouped in other clusters. Such analysis was meant to avoid selection of parents from genetically homogenous clusters, and to maintain a relatively broad genetic base.

The largest intra-cluster distance was recorded for cluster VI (174.228) followed by clusters III (147.061) and I (132.719) the lines included in cluster I, III and VI were more diverse than those in the other clusters. Heterosis is generally attributed to genetic divergence among the parental lines in involved in the crosses. Nevertheless, the genetic divergence for the maximum expression of the heterotic effect has a limit (Arunachalam and Bandyopadhyay, 1984) and (Moll et al., 1965).

The cluster mean values showed a wide range of variation for all the traits under study (Table 3). Cluster VI was characterized with high mean values for hundred grain weight, kernel length, kernel L/B ratio and grain yield per plant. Cluster II exhibited a low mean for plant height, hundred grain weight, grain length, kernel length, kernel $\mathrm{L} / \mathrm{B}$ ratio and grain yield per plant. Cluster IV had high mean for plant height, grain breadth and kernel breadth. Cluster $\mathrm{V}$ had high mean for panicle length and grain L/B ratio. Cluster III had high mean for grain length and early for days to 50 per cent flowering.

In all the combinations of inter cluster distance each character is ranked on the basis of inter cluster distances. Rank $\mathrm{I}$ is given to the character having highest mean difference and rank $\mathrm{P}$ is given to the character having lowest mean difference, where $\mathrm{P}$ is the numbers of characters. Percentage contribution of each character is calculated on the basis of occurrence of these ranks. With 46.69 per cent contribution, the grain yield per plant, 18.28 per cent for kernel length and with 14.96 per cent contribution of hundred grain weight were the major force of discrimination among the genotypes tested (Table 6). Similar finding were made by Karthikeyan (2002), Sabesan and Saravanan (2008), Rajesh et al., (2010) and Kumari Priyanka et al., (2015) for filled grains per panicle, hundred grain weight and grain yield per plant, respectively. Plant height had the minimum ( 0.17 per cent) contribution to the total divergence. Similar results were reported by Senapati and Sarkar (2005).

Considering the importance of genetic distance, relative contribution of characters towards total divergence and yield potential of genotypes, the present investigation suggests that parental lines selected from cluster II (ADT 47 and ADT 49) for slender grains. Cluster VI (CSR 30, ANANDA, MARANTHONDI, SWATHI, MTU1010, ASD16, ASD19, KARMA, MAHSURI, JALAKARA PONNI, SHYAMALA, ANNAPURNA, ASD 18 and GAYATHRI) for high mean for hundred grain weight, kernel length, kernel L/B ratio and grain yield per plant. Cluster IV (POORNIMA and SWARNA) for high mean for plant height, grain breadth and kernel breadth could be used in a hybridization programme, since hybridization between divergent parents is likely to produce wide variability and transgressive segregations. Crosses between unrelated lines tend to exhibit heterosis. Thus, 
diverse lines from different clusters should be chosen for crossing in a hybrid rice breeding programme.

\section{References}

Arunachalam, V. and A. Bandyopadhyay. 1984. Limit to genetic divergence for occurrence of heterosis and experimental evidence for occurrence of heterosis and experimental evidence from crop plant. Indian J. Genet., 44: 548-554.

Bhati, P.K., S.K. Singh, S.Y. Dhurai and Amita Sharma. 2015. Genetic divergence for quantitative traits in rice germplasm. Electronic J. Plant Breed., 6(2): 528-534.

Chaturvedi, H.P. and D.M. Maurya. 2005. Genetic divergence analysis in rice (Oryza sativa L.). Adv. Plant Sci., 18(1): 349-353.

Foreign Agriculture Services/USDA, Office of Global Analysis, April 2013. http:// www.fas.usda.gov/psdonlir.

Kandamoorthy, S. and R. Govindarasu. 2005. Genetic divergence in extra early rice (Oryza sativa L.) under two culture systems. Indian J. Genet., 65(1): 43-44.

Karthikeyan, T. 2002. Studies on genetic divergence and genotype $\times$ environment interaction in rice (Oryza sativa L.). M.Sc. (Ag.) Thesis, Annamalai University, Tamilnadu.

Kumari Priyanka, H.K. Jaiswal, Showkat A. Waza and T. Sravan. 2015. Genetic divergence in indigenous aromatic rice (Oryza sativa L.). Electronic J. Plant Breed., 6(4): 1096-1102.

Mahalanobis, P.C. 1936. On the generalized distance in statistics. Proc. Nat. Inst. Sci., 2: 49-55.

Moll, R.H., J.H. Lonnquist and E.C. Johnson. 1965. The relation of heterosis and genetic divergence in maize. Genetics, 52: 139-144.

Rajesh, T., K. Paramasivam and S. Thirumeni. 2010. Genetic divergence in land races of rice. Electronic J. Plant Breed., 1(2): 199204.

Rama, T. 1992. Heterosis and in breeding depression in rice. IRRI Newsletter, 17(5): 7.

Rao, C.R. 1952. Advanced statistical method in biometrical Research. John Wiley and Sons Inc., New York.

Sabesan, T., K. Saravanan and A. Anandan. 2009. Genetic divergence analysis for certain yieldand quality traits in rice (Oryza sativa L.). Grown in irrigated Saline low land of Annamalai Nagar, South India. Central European J. Agric., 10(4): 405-410.

Sabesan, T.and K. Saravanan. 2008. Genetic divergence analysis in rice (Oryza sativa L.). Paper presented in golden jubilee commemorative national seminar on "fifty years of Indian Agriculture: problems, prospects and Future thrust", Annamalai University, Tamil Nadu, India 20-21 March, 2008, pp. 14.

Sarawagi, A.K. and Rita Binse. 2007. Studies on genetic divergence of aromatic rice germplasm for agro morphological and quality characters. Oryza, 44(1): 74-76.

Satheeshkumar, P. and K. Saravanan. 2012. Genetic divergence analysis for grain yield and quality traits in rice (Oryza satia L.). Plant Archives, 12(2): 639-644.

Senapati, B.K. and G. Sarkar. 2005. Genetic divergence in tall indica rice (Oryza sativa L.) under rainfed saline soil of Sundarban. Oryza, 42(1): 70-72.

Verma, V.S. and R.K. Mehta. 1976. Genetic divergence in Lucerne. J. Maharashtra Agr. Univ., 1: 23-28.

\section{How to cite this article:}

Thippannagari Radha, P. Satheesh Kumar and Saravanan, K. 2018. Genetic Divergence for Quantitative and Quality Traits in Rice (Oryza sativa L.). Int.J.Curr.Microbiol.App.Sci. 7(05): 494500. doi: https://doi.org/10.20546/ijcmas.2018.705.062 